Scientific journal

PHYSICAL AND MATHEMATICAL EDUCATION

Has been issued since 2013

Науковий журнал

ФІЗИКО-МАТЕМАТИЧНА ОСВІТА

Видається 32013.

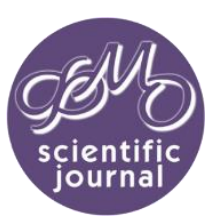

p-ISSN 2413-1571

e-ISSN 2413-158X

DOI: $10.31110 / 2413-1571$

https://fmo-journal.org/

DOI 10.31110/2413-1571-2021-032-6-003

Удк 37.014.1

\section{СТАВЛЕННЯ \\ ДО МАСОВИХ ВІДКРИТИХ ОНЛАЙН-КУРСІВ ЯК ФОРМИ НЕФОРМАЛЬНОЇ ОСВІТИ}

\author{
Неля ДЕГТЯРЬОВА \\ Сумський державний педагогічний університет \\ імені А.С. Макаренка, Україна \\ degtyarevanv@fizmatsspu.sumy.ua \\ https://orcid.org/0000-001-9590-4915 \\ Олена ГОНТАР \\ Сумський державний педагогічний університет \\ імені А.С. Макаренка, Україна \\ helenhontar18@gmail.com \\ Галина ВЕРНИДУБ \\ Відокремлений структурний підрозділ \\ «Сумський фаховий коледж Сумського національного \\ аграрного університету», Україна \\ ladygalinka29@gmail.com \\ https://orcid.org/0000-0002-6654-2983
}

\section{АНОТАЦІЯ}

Формулювання проблеми. Неформальна освіта стає все більш затребуваною. До неформальної освіти відносять професійні курси з визначеною чільовою аудиторією, професійне стажування, масов відкриті онлайн курси, громадську освіту. Саме масові відкриті онлайн курси є затребуваними і їх кількість постійно збільшується. Такі курси покликані розширити уявлення про конкретний предмет вивчення або допомогти розібратися в абсолютному новому напрямі. Масові відкрит курси пропонуються як на безоплатній основі, так і платні. На даний час зустрічається думка, що вони стають вимушено популярними з причини того, що заклади вищої освіти мають продемонструвати того, що заклади вищої освіти мають продемонструвати впровадження в освітній процес елементів неформальної освіти. Метою
даного дослідження було з'ясувати ставлення слухачів до масових відкритих онлайн курсів та причин вибору саме такого способу освіти що дасть змогу вибудувати критерії побудови якісного онлайн курсу.

матеріали і методи: системний аналіз наукової та методично літератури, порівняння та синтез теоретичних розвідок вітчизняних вчених, анкетування, узагальнення власного досвіду.

Результати. Були проаналізовані платформи, на яких доступні платні та безкоштовні масові онлайн курси: ВУМ, Дія. Цифрова освіта EdEra, Geek Brains, Laba, Prometheus, Wisecow. В роботі наводяться посилання на вказані платформи та тематика представлених курсів. Зогляду на популярність саме чих курсів серед українських користувачів було проведено опитування щодо причин вибору конкретно платформи та таких, що спонукали саме до неформальної освіти замість навчання в класах шкіл або аудиторіях університетів.

Висновки. Результати дали підстави стверджувати, що головними причинами, з яких користувачі розпочинають пошук та проходження онлайн курсів $\epsilon$ власне бажання саморозвитку та вимога навчального закладу. Це може свідчити як про інформування таким чином щодо існування такої моживості, а також про формальний підхід до такої освіти, що і буде вивчатися в подальщих розвідках авторів. Найчастіше респонденти обирали платформи Prometheus, Дія. Циррова освіта ma EdEra. При цьому курси на безоплатній основі обирали 65\%, а платні проходили $35 \%$ анкетованих, що також свідчить про те, що на даний час такі курси $\epsilon$ доступними. Масові відкриті онлайн курси є альтернативою для підвищення власної кваліфікації, а також для того, щоб зрозуміти чи підходить конкретний напрям для роботи конкретній людині.

ключОвІ СЛОВА: неформальна освіта, масові відкриті онлайн курси, Prometheus, Дія. Цифрова освіта, EdEra.

\section{ATTITUDE \\ TOWARDS MASS OPEN ONLINE COURSES AS A FORM OF NON-FORMAL EDUCATION}

\author{
Nelia DEHTIAROVA $\square$ \\ Makarenko Sumy State Pedagogical University, \\ Ukraine \\ degtyarevanv@fizmatsspu.sumy.ua \\ https://orcid.org/0000-001-9590-4915 \\ Olena HONTAR \\ Makarenko Sumy State Pedagogical University, \\ Ukraine \\ helenhontar18@gmail.com \\ Halyna VERNYDUB \\ Separate Structural Subdivision \\ "Sumy professional college \\ of Sumy National Agrarian University», Ukraine \\ ladygalinka29@gmail.com \\ https://orcid.org/0000-0002-6654-2983
}

\begin{abstract}
Formulation of the problem. Non-formal education is becoming more and more popular. Non-formal education includes professional courses with a specific target audience, professional internships, mass open online courses, public education. Online courses that are in demand and their number is constantly increasing. Such courses are designed to expand the understanding of a particular subject of study or help to understand a completely new direction. Open courses are offered both on a free and paid basis. At present, it is believed that they are becoming popular due to the fact that higher education institutions must demonstrate the introduction of elements of non-formal education in the educational process. The purpose of this study was to find out the attitude of students to the massive open online courses and the reasons for choosing this type of education, which will allow you to build criteria for building a quality online course.

Materials and methods: systematic analysis of scientific and methodological literature, comparison and synthesis of theoretical investigations of domestic scientists, questionnaires, generalization of personal experience.

Results. Platforms on which paid and free online courses are available were analyzed: VUM, Dija. Digital Education, EdEra, Geek Brains, Laba, Prometheus, Wisecow. The paper provides links to these platforms and topics of the courses presented. Given the popularity of these courses among Ukrainian users, a survey was conducted on the reasons for choosing a particular platform and those that encouraged non-formal education instead of studying in school classrooms or university classrooms.

Conclusions. The results gave grounds to claim that the main reasons why users start searching and taking online courses are their own desire for self-development and the requirement of the educational institution. This may indicate both informing about the existence of such a possibility, as well as a formal approach to such education, which will be studied in further research by the authors. Most often, respondents chose Prometheus, Action platforms. Digital Education and EdEra. At the same time, 65\% chose free courses, and $35 \%$ took paid courses, which also indicates that such courses are currently available. Massive open online courses are an alternative to improving your skills, as well as to understand whether a particular direction is suitable for a particular person.
\end{abstract}

KEYWORDS: non-formal education, mass open online courses, Prometheus, Diia. Digital education, EdEra.
Для цитування:

Дегтярьова Н., Гонтар О., Вернидуб Г. Ставлення до масових відкритих онлайн Том 32. № 6. C. 18-22. DOI: https://doi.org/10.31110/2413-1571-2021-032-6-00 ocsima, 32(6). 18-22. https://doi.org/10.31110/2413-1571-2021-032-6-003

For citation Dehtiarova, N., Hontar, O. \& Vernydub, H. (2021). Attitude towards mass open online courses as a form of non-formal education. Physical and Mathematical Education, 32(6), 18-22. https://doi.org/10.31110/2413-1571-2021-032-6-003 Dehtiarova, N., Hontar, O. \& Vernydub, H. (2021). Stavlennia do masovykh vidkrytykh onlain-kursiv yak formy neformalnoi osvity [Attitude towards mass open online courses as a form of non-formal education]. Fizyko-matematychna osvita - Physical and Mathematical Education, 32(6), 18-22. https://doi.org/10.31110/2413-1571-2021-032-6-003 


\section{ВСТУП}

Неформальна освіта як необхідність почала сприйматися у контексті нових вимог при акредитації спеціальностей закладів вищої освіти. Проте перші кроки в цьому напрямі були зроблені задовго до цього з причини глобалізації. Інформація стала доступною не залежно від місцезнаходження користувача та його освіти. I перші курси, гуртки, відеоуроки, різі види навчання поза межами традиційної освіти були доступними незалежно від того чи називали на той час це неформальною освітою. До неформальної освіти відносять професійні курси з визначеною цільовою аудиторією, професійне стажування, масові відкриті онлайн курси, громадську освіту.

В навчальному посібнику Павлик Н. аналізуються різні підходи до означення неформальної освіти. Автор досліджувала рекомендації Європейського центру розвитку професійної освіти для країн Євросоюзу, Асамблеї Ради Європи, наукові дослідження, словники (Павлик, 2017). Провівши контент-аналіз, авторка пропонує власне трактування неформальної освіти «як процесу додаткового цілеспрямованого діалогічного навчання, виховання й розвитку молоді, організованого поза межами змісту, форм і методів освітніх установ та державних інституцій» (Павлик, 2017). Не можемо погодитися з таким означенням стосовно категорії осіб, які навчаються, оскільки неформальна освіта не має обмежень щодо віку. За даними дослідження проведеними співрозробниками платформи Prometheus середній вік слухачів курсів становить 30 років (Сардалова, 2018). А у дослідженні Литовченко О. зазначається, що неформальна освіта є складовою безперервної освіти. Уміння та компетентності набуваються та вдосконалюються протягом життя (Литовченко, 2020). I це стосується як ключових компетентностей, так і фахових (професійних).

У інших дослідженях автори відзначають, що неформальна освіта поступово стає трендом. Це сприяє як саморозвитку окремої особистості, так і формуванню громадянського суспільства в цілому (Аніщенко \& Лук'янова \& Прийма, 2017). Цю тезу можна підтвердити тим, що на даний час заклади вищої освіти не у повній мірі задовольняють потреби здобувачів у змісті навчання. Різні освітні програми представляють бачення переважно розробників, часто не враховуючи сучасні виклики, актуальність тієї чи іншої дисципліни в контексті отримання конкретної спеціальності. Також знання та уміння, що здобувалися десять років тому стають вже неактуальними або неповними. Тому альтернативна до формальної освіта і стає все більш популярною. Саморозвиток дає іноді кращі результати, ніж навчання в офіційних установах. Сприйняття, зацікавленість слухача, якість отриманих ним знань та умінь залежить і від якості матеріалу та уміння викладати матеріал різній цільовій аудиторії. Також важливими факторами при онлайн освіті $€$ :

- мотивація до закінчення курсів та подальша робота в обраному напрямі. Як демонструють результати дослідження (Rudenko et al, 2021) вирішальним фактором при дистанційній освіті, онлайн навчанні є мотивація того, хто навчається. За даними розробників платформи ВУМ завершуваність курсів становить біля 30\% , а в Prometheus - $11 \%$ (Сардалова, 2018);

- умови для забезпечення виходу до глобальної мережі та використання потенціалу власних цифрових пристроїв, які стають основою до безперервної освіти, використання різних технологій в освітньому процесі (Semenikhina et al., 2019).

Мета статті: з'ясувати ставлення слухачів до масових відкритих онлайн курсів та причини вибору саме такого способу освіти, що дасть змогу вибудувати критерії побудови якісного онлайн курсу.

МЕТоДИ ДОсЛІДЖЕНня: системний аналіз наукової та методичної літератури, порівняння та синтез теоретичних розвідок вітчизняних вчених, анкетування, узагальнення власного досвіду.

\section{РЕЗУЛЬТАТИ ДОСЛІДЖЕННЯ}

Під поняттям неформальної освіти розуміємо такий вид альтернативної до формальної освітньої діяльності, який спланований самим суб'єктом такої діяльності та передбачає набуття компетентностей в обраній суб'єктом галузі. Платформи, де пропонуються відкриті онлайн курси, здійснюють моніторинг потреб слухачів. Кількість платформ з курсами для саморозвитку також збільшується зі збільшенням попиту на них. В таблиці 1 представлено перелік таких ресурсів з основними напрямами для освіти.

Таблиця 1.

Огляд ресурсів для самоосвіти

\begin{tabular}{|c|c|c|}
\hline $\begin{array}{c}\text { Назва платформи, ресурсу, } \\
\text { URL }\end{array}$ & Тематика & Примітка \\
\hline $\begin{array}{l}\text { BУM } \\
\text { (https://vumonline.ua/) }\end{array}$ & $\begin{array}{l}\text { Особиста ефективність } \\
\text { Розуміння світового контексту } \\
\text { Комунікативна ефективність } \\
\text { Взаємодія з органами влади } \\
\text { Соціальне підприємництво } \\
\text { Формування і розвиток громад }\end{array}$ & $\begin{array}{l}\text { Курси є безкоштовними і соціально- } \\
\text { орієнтованими }\end{array}$ \\
\hline $\begin{array}{l}\text { Дія. Цифрова освіта } \\
\text { (https://osvita.diia.gov.ua/) }\end{array}$ & $\begin{array}{l}\text { Соціальний напрямок } \\
\text { Екологія } \\
\text { IT } \\
\text { Фінанси } \\
\text { Підприємництво } \\
\text { Медіаграмотність } \\
\text { Освіта }\end{array}$ & $\begin{array}{l}\text { Ресурс безкоштовний, } \\
\text { Представлений освітніми серіалами, } \\
\text { гайдами, подкастами, корисними } \\
\text { посиланнями, словником сучасного сленга }\end{array}$ \\
\hline $\begin{array}{l}\text { EdEra } \\
\text { (https://www.ed-era.com/) }\end{array}$ & $\begin{array}{l}\text { Освіта } \\
\text { Соціальні курси } \\
\text { Політика }\end{array}$ & $\begin{array}{l}\text { Курси є безкоштовними, } \\
\text { наявна бібліотека з посібниками та } \\
\text { журналами, доступ до яких безкоштовний }\end{array}$ \\
\hline
\end{tabular}




\begin{tabular}{|c|c|c|}
\hline & $\begin{array}{l}\text { Компетентності } \\
\text { Економіка } \\
\text { Курси для школярів з предметів для } \\
\text { підготовки до ЗНО }\end{array}$ & \\
\hline $\begin{array}{l}\text { Geek Brains } \\
\text { (https://geekbrains.com.ua/) }\end{array}$ & $\begin{array}{l}\text { Графічний дизайн } \\
\text { Вебдизайн } \\
\text { Аналітика } \\
\text { Менеджмент } \\
\text { Інформаційна безпека } \\
\text { Програмування } \\
\end{array}$ & $\begin{array}{l}\text { Курси } є \text { платними, навчання триває рік і } \\
\text { більше }\end{array}$ \\
\hline $\begin{array}{l}\text { Laba } \\
\text { (https://l-a-b-a.com/uk/) }\end{array}$ & $\begin{array}{l}\text { HR і рекрутинг } \\
\text { Маркетинг і PR } \\
\text { Фінанси } \\
\text { Бізнес і управління } \\
\text { Програми (офісні програми) } \\
\end{array}$ & $\begin{array}{l}\text { Курси є платними, тривалість навчання від } \\
\text { 5ти тижнів, російська мова інтерфейсу }\end{array}$ \\
\hline $\begin{array}{l}\text { Prometheus } \\
\text { (https://prometheus.org.ua/) }\end{array}$ & $\begin{array}{l}\text { IT } \\
\text { Аналіз даних } \\
\text { Іноземні мови } \\
\text { Громадянська освіта } \\
\text { Журналістика } \\
\text { Місцеве самоврядування } \\
\text { Особистий розвиток } \\
\text { Охороно здоров'я } \\
\text { Для освітян } \\
\text { Інші }\end{array}$ & $\begin{array}{l}\text { Курси є безкоштовними та окремі } \\
\text { платними, навчання рекомендовано від 5ти } \\
\text { тижнів }\end{array}$ \\
\hline $\begin{array}{l}\text { Wisecow } \\
\text { (https://wisecow.com.ua/) }\end{array}$ & $\begin{array}{l}\text { Література } \\
\text { Кіно } \\
\text { Мистецтво } \\
\text { Історія } \\
\text { Журналістика } \\
\text { Мода } \\
\text { Міста } \\
\text { Соціум }\end{array}$ & $\begin{array}{l}\text { Платформа містить набір лекцій, які також } \\
\text { можна переглядати на yotube, } \\
\text { лекції безкоштовні }\end{array}$ \\
\hline
\end{tabular}

3 причини орієнтування на внутрішній попит у даному аналізі не розглядалися англомовні платні ресурси, на кшталт Coursera, яких також у глобальній мережі пропонується достатня кількість для задоволення різних освітніх вимог користувачів.

Затребуваність курсу, майстер-класу чи іншого визначається його якістю, наповненістю практичним матеріалом, корисністю та умінням його автора подати матеріал. Дуже важливим у цьому контексті стає саме остання вказана складова. Часто затребувані на даний час IT курси стають недоступними для усвідомлення з причини невміння автора подати матеріал, правильно структурувати курс.

Було проведено дослідження щодо сприйняття курсів різними категоріями осіб, які навчалися. На початку з'ясовувалося критерії, за якими обираються ті чи інші платформи, конкретні курси. Також анкетування містило питання про причини, за яких з'явилася необхідність пройти курси, а також чи були пройдені курси у повному обсязі.

До анкетування залучилися здобувачі освіти, науково-педагогічні працівники, фахівці інших спеціальностей м. Київ, м. Кременець, М. Ірпінь, м. Суми, м. Умань. Були долучені такі заклади освіти: Сумський державний педагогічний університет імені А.С. Макаренка, Кременецька обласна гуманітарно-педагогічна академія ім.Тараса Шевченка, Уманський державний педагогічний університет імені Павла Тичини, Відокремлений структурний підрозділ "Ірпінський фаховий коледж національного університету біоресурсів і природокористування України". Всього прийняли участь 143 респондента. 3 них здобувачів освіти - 58\%, вчителів, викладачів (тьюторів, кураторів онлайн школи) - 36\%, фахівців не пов'язаних з освітою та викладанням - 5 \%. На питання «Чи розумієте ви поняття «неформальна освіта»?» $47 \%$ респондентів відповіли, що повністю усвідомлюють поняття та його означення, 45\% опитаних мають приблизне уявлення, а $8 \%$ не знають такого поняття.

В опитуванні були перераховані платформи, представлені в таблиці 1. Пропонувалося вибрати декілька варіантів платформ, з якими анкетовані знайомі. Результат представлено на рисунку 1.

Онлайн курси проходило 70\% респондентів. 3 них платні опановували 35\%, а безкоштовними працювали $65 \%$. Найпоширенішими причинами вибору курсу була самоосвіта (44,6\%) та вимога за місцем навчання, роботи $(29,7 \%)$. Серед інших причин вказували підвищення кваліфікації, необхідність стажування, бажання створити власний курс тощо. Розподіл відповідей щодо причин обрання курсів показано на рисунку 2.

Респондентами вказано різну кількість курсів, які розпочатих на даний момент - від 1 до 12. Також вони вказали, що незакінченими є від 1 до 5. Причинами такої ситуації називають такі:

- «не вистачає часу, планую повернутися пізніше» - 50\%;

- «знання з даної області перестали бути актуальними для мене» - 10\%;

- «матеріал не відповідає заявленій назві» - 10\%;

- «розробник курсу подавав матеріал неякісно, не цікаво» - 7\%; 
- складні завдання, тести для закріплення - 3\%;

- незакінчених курсів не маю - 10\%;

- інші відповіді («стало не цікаво», «не маю бажання», «відклала з причини хвороби» тощо) - 10\%.

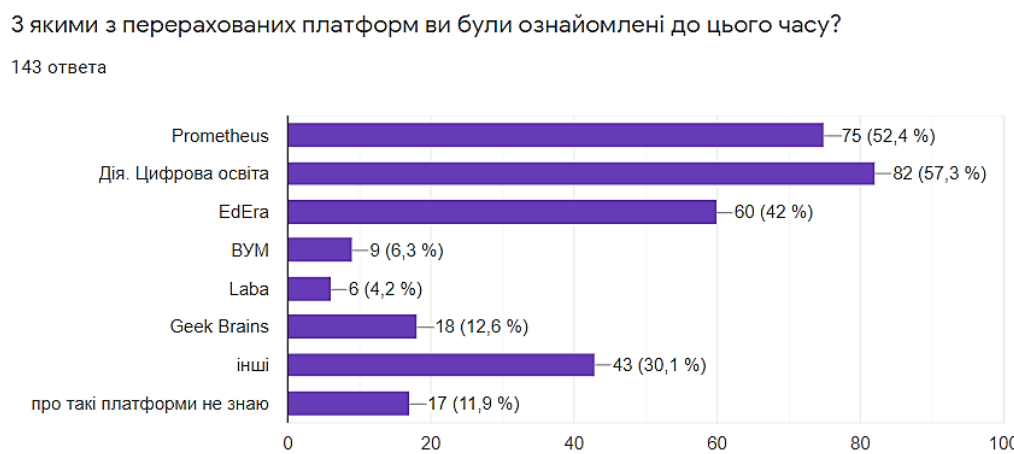

Рис. 1. Результати опитування щодо неформальної освіти

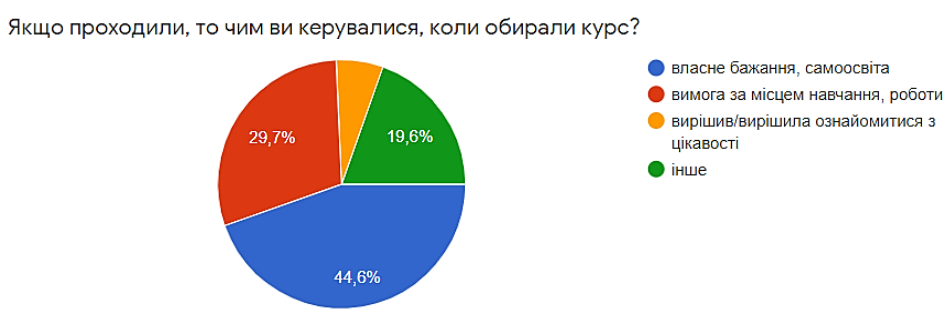

Рис. 2. Результати опитування щодо неформальної освіти

\section{ВИСНОВКИ ТА ПЕРСПЕКТИВИ ПОДАЛЬШОГО ДОСЛІДЖЕННЯ}

Результати опитування продемонстрували, що неформальна освіта дійсно стала більш популярною з причини вимог, які ставляться сьогодні до закладів вищої освіти у цьому контексті. Проте даний фактор позитивно впливає на інформування учнів, студентів, фахівців різних спеціальностей щодо такої можливості. Можна припустити, що тоді близько 30\% анкетованих, які обрали масові відкриті курси підходять до їх проходження формально, тому даний факт іє наступним напрямом для вивчення більш детально авторами цієї проблеми. 3 вищезазначеного можна зробити наступні висновки:

1. На даний час неформальна освіта $€$ затребуваною. Причинами попиту на масові відкриті онлайн курси $є$ недостатня узгодженість пропонованого змісту навчання у закладах загальної середньої та закладах вищої освіти сучасним вимогам до компетенцій випускників, а також неактуальність окремих компонентів компетентностей осіб, які отримали освіту раніше.

2. У глобальній мережі пропонуються платні та безкоштовні курси, вартість яких доступна для осіб, зацікавлених в їх проходженні. Найпопулярнішими з переліку україномовних курсів $€$ Prometheus, Дія. Цифрова освіта та ЕdEra.

3. Найпоширенішими причинами вибору саме такої форми освіти є власна потреба та вимога за місцем роботи чи навчання. Проте треба зауважити, що питання, де визначалися кількість курсів розпочатих слухачами (від 2х до 12 , а таких понад 70\%) може свідчити про уже власну зацікавленість у подальшому саморозвитку.

4. Залишається актуальним необхідність забезпечення користувача сучасним технічним та програмним забезпеченням та якісним доступом до глобальної мережі.

5. Все вищезазначене дає підстави стверджувати, що для створення якісного курсу потрібно вивчити попит на такий напрям, вивчити найпопулярніші курси та визначити що саме робить їх затребуваними, забезпечити якість матеріалу, організувати якісне, зрозуміле, зацікавлююче його подання, дотримуватися рекомендацій щодо створення онлайн курсів, визначитися з популярною платформою, на якій можна представити власну доробку.

\section{СПИСОК ВИКОРИСТАНИХ ДЖЕРЕЛ}

1. Pokryshen, D. (2021). Information system of accounting for professional development of educators in formal and non-formal education. Фізико-математична освіта, 31(5), 6-10. https://doi.org/10.31110/2413-1571-2021-031-5-001.

2. Rudenko, Y., Naboka, O., Korolova, L., Kozhukhova, K., Kazakevych, O., \& Semenikhina, O. (2021). Online learning with the eyes of teachers and students in educational institutions of ukraine. TEM Journal, 10(2), 922-931. https://doi.org/10.18421/TEM102-55

3. Semenikhina, O. V., Drushlyak, M. G., Bondarenko, Y. A., Kondratiuk, S. M., \& Ionova, I. M. (2019). Open educational resources as a trend of modern education. Paper presented at the 2019 42nd International Convention on Information and Communication Technology, Electronics and Microelectronics, MIPRO 2019 - Proceedings, 779-782. https://doi.org/10.23919/MIPRO.2019.8756837.

4. Semenikhina, O., Drushlyak, M., Lynnyk, S., Kharchenko, I., Kyryliuk, H., \& Honcharenko, O. (2020). On computer support of the course "fundamentals of microelectronics" by specialized software: The results of the pedagogical experiment. TEM Journal, 9(1), 309-316. https://doi.org/10.18421/TEM91-43.

5. Semenikhina, E., Drushlyak, M., Dehtiarova, N., Bondarenko, Y., Kondratiuk, S. (2019) Cloud-based Service GeoGebra and Its Use in the Educational Process: the BYOD-approach. TEM Journal, 8(1), 65-72. https://doi.org/10.18421/TEM81-08.

6. Yurchenko, A., Drushlyak, M., Sapozhnykov, S., Teplytska, S., Koroliova, L., \& Semenikhina, O. (2021). Using online IT-industry courses in the computer sciences specialists' training. International Journal of Computer Science and Network Security. 21(11), 97-104. http://paper.ijcsns.org/07_book/202111/20211113.pdf 
7. Аніщенко, О., Лук'янова, Л., \& Прийма, С. (2017). Неформальна освіта дорослих - освітній тренд XXI століття. Рідна школа. 11 -12. 3-7. https://lib.iitta.gov.ua/710422/1/Anishchenko\%2C\%20Lukianova\%2C\%20Pryima\%20_\%20Non-formal\%20education\%20of\%20adults.pdf.

8. Будянський, Д. В., Друшляк, М. Г., Семеніхіна, О. В., Харченко, І. І., Горбачук, В. О., \& Чашечникова, О. С. (2021). Типологія електронних ресурсів у формуванні риторичної культури фахівця. Інформаційні технології $і$ засоби навчання, 81(1), 82-96. https://doi.org/10.33407/itlt.v81i1.4292

9. Глазунова, О.Г., Гуржій, А.М., Волошина, Т.В., Корольчук, В.І., \& Пархоменко, О.В. (2020). Неформальна освіта майбутніх фахівців з інформаційних технологій: організація, контент, інструменти. Фізико-математична освіта, 1(23), $29-35$. https://doi.org/10.31110/2413-1571-2020-023-1-005.

10. Литовченко, О. (2020). Неформальна освіта дітей та молоді: європейські цілі і цінності. Ціннісно-орієнтований підхід в освіті і виклики євроінтеграції: матер. міжнар. наук.-метод. конф. (Суми, 29-30 травня 2020 р.). 272 c. https://essuir.sumdu.edu.ua/bitstreamdownload/123456789/78513/3/konferentsiya_values.pdf.pdf

11. Носенко, Ю.Г., \& Сухіх, А.С. (2020). Відкрита наука в контексті побудови суспільства знань і цифрових перетворень європейського простору. Фізико-математична освіта, 4(26), 85-92. https://doi.org/10.31110/2413-1571-2020-026-4-015.

12. Павлик, Н. (2017). Теорія і практика організації неформальної освіти молоді. Житомир: Вид-во ЖдУ ім. І. Франка. http://eprints.zu.edu.ua/29815/1/ПавликНеформальнаОсвітаМонографія.pdf.

13. Сардалова, Е. (2018). Онлайн-курси в Україні вчать навчати, спілкуватись і бути громадянами. Суспільство. Радіо Свобода. https://www.radiosvoboda.org/a/online-osvita-v-ukraini/29672247.html

14. Семеніхіна, О.В., Юрченко, А.О., Сбруєва, А.А., Кузьмінський, А.І., Кучай, О.В., \& Біда, О.А. (2020). Відкриті цифрові освітні ресурси у галузі IT: кількісний аналіз. Інформаційні технології і засоби навчання, 75(1), 331-348. https://doi.org/10.33407/itlt.v75i1.3114.

15. Фонарюк, О.В. (2020). Неформальна математична освіта: аналіз веб-ресурсів. Фізико-математична освіта, 4(26), 119-123. https://doi.org/10.31110/2413-1571-2020-026-4-020.

\section{REFERENCES (TRANSLATED AND TRANSLITERATED)}

1. Pokryshen, D. (2021). Information system of accounting for professional development of educators in formal and non-formal education. Fizyko-matematychna osvita - Physical and Mathematical Education, 31(5), 6-10. https://doi.org/10.31110/2413-1571-2021-031-5-001.

2. Rudenko, Y., Naboka, O., Korolova, L., Kozhukhova, K., Kazakevych, O., \& Semenikhina, O. (2021). Online learning with the eyes of teachers and students in educational institutions of ukraine. TEM Journal, 10(2), 922-931. https://doi.org/10.18421/TEM102-55

3. Semenikhina, O. V., Drushlyak, M. G., Bondarenko, Y. A., Kondratiuk, S. M., \& lonova, I. M. (2019). Open educational resources as a trend of modern education. Paper presented at the 2019 42nd International Convention on Information and Communication Technology, Electronics and Microelectronics, MIPRO 2019 - Proceedings, 779-782. https://doi.org/10.23919/MIPRO.2019.8756837.

4. Semenikhina, O., Drushlyak, M., Lynnyk, S., Kharchenko, I., Kyryliuk, H., \& Honcharenko, O. (2020). On computer support of the course "fundamentals of microelectronics" by specialized software: The results of the pedagogical experiment. TEM Journal, 9(1), 309-316. https://doi.org/10.18421/TEM91-43.

5. Semenikhina, E., Drushlyak, M., Dehtiarova, N., Bondarenko, Y., Kondratiuk, S. (2019) Cloud-based Service GeoGebra and Its Use in the Educational Process: the BYOD-approach. TEM Journal, 8(1), 65-72. https://doi.org/10.18421/TEM81-08.

6. Yurchenko, A., Drushlyak, M., Sapozhnykov, S., Teplytska, S., Koroliova, L., \& Semenikhina, O. (2021). Using online IT-industry courses in the computer sciences specialists' training. International Journal of Computer Science and Network Security. 21(11), 97-104. http://paper.ijcsns.org/07_book/202111/20211113.pdf

7. Anishchenko, O., Lukianova, L., \& Pryima, S. (2017). Neformalna osvita doroslykh - osvitnii trend XXI stolittia [Non-formal adult education is an educational trend of the 21st century]. Ridna shkola - Native school. 11-12. 3-7. https://lib.iitta.gov.ua/710422/1/Anishchenko\%2C\%20Lukianova\%2C\%20Pryima\%20_\%20Non-formal\%20education\%20of\%20adults.pdf (in Ukrainian).

8. Budianskyi, D., Drushlyak M., Semenikhina, O., Kharchenko, I., Horbachuk, V., \& Chashechnikova, O. (2021). Typolohiia elektronnykh resursiv u formuvanni rytorychnoi kultury fakhivtsia [Electronic resources typology in the formation of specialist's rhetoric culture]. Information Technologies and Learning Tools - Informatsiini tekhnolohii i zasoby navchannia, 81(1), 82-96. https://doi.org/10.33407/itlt.v81i1.4292 (in Ukrainian).

9. Glazunova, O., Gurzhiy, A., Voloshyna, T., Korolchuk, V. \& Parhomenko, O. (2020). Neformalna osvita maibutnikh fakhivtsiv z informatsiinykh tekhnolohii: orhanizatsiia, kontent, instrumenty [Informal education of future spesialist of information technology: organization, content, instruments]. Fizyko-matematychna osvita - Physical and Mathematical Education, 1(23), 29-35. https://doi.org/10.31110/2413-1571-2020023-1-005 (in Ukrainian)..

10. Lytovchenko, O. (2020). Non-formal education of children and youth: European goals and values [Neformalna osvita ditei ta molodi: yevropeiski tsili i tsinnosti]. Tsinnisno-oriientovanyi pidkhid v osviti $i$ vyklyky yevrointehratsii - Value-oriented approach in education and challenges of European integration. https://essuir.sumdu.edu.ua/bitstream-download/123456789/78513/3/konferentsiya_values.pdf.pdf (in Ukrainian).

11. Nosenko, Yu., \& Sukhikh, A. (2020). Vidkryta nauka v konteksti pobudovy suspilstva znan i tsyfrovykh peretvoren yevropeiskoho prostoru [Open science in terms of building a knowledge society and digital transformations of the european space]. Fizyko-matematychna osvita Physical and Mathematical Education, 4(26), 85-92. https://doi.org/10.31110/2413-1571-2020-026-4-015. (in Ukrainian).

12. Pavlyk, N. (2017). Teoriia i praktyka orhanizatsii neformalnoi osvity molodi [Theory and practice of non-formal education of youth]. Zhytomyr: Vyd-vo ZhDU im. I. Franka. http://eprints.zu.edu.ua/29815/1/ПавликНеформальнаОсвітаМонографія.pdf (in Ukrainian).

13. Sardalova, E. (2018). Onlain-kursy v Ukraini vchat navchaty, spilkuvatys i buty hromadianamy [Online courses in Ukraine teach to teach, communicate and be citizens]. Suspilstvo. Radio Svoboda - Society. Radio Liberty. https://www.radiosvoboda.org/a/online-osvita-vukraini/29672247.html (in Ukrainian).

14. Semenikhina, O. B., Yurchenko, A. O., Sbruieva, A. A., Kuzminskyi, A. I., Kuchai, O. B., \& Bida, O. A. (2020). Vidkryti tsyfrovi osvitni resursy u haluzi IT: kilkisnyi analiz [The open digital educational resources in IT-technologies: quantity analysis]. Informatsiini tekhnolohii $i$ zasoby navchannia - Information Technologies and Learning Tools, 75(1), 331-348. https://doi.org/10.33407/itlt.v75i1.3114 (in Ukrainian).

15. Fonariuk, O. (2020). Neformalna matematychna osvita: analiz veb-resursiv [Informal mathematical education: analysis of web-resources]. Fizyko-matematychna osvita - Physical and Mathematical Education, 4(26), 119-123. https://doi.org/10.31110/2413-1571-2020-026-4-020 (in Ukrainian).

\section{(CC) BY-NC-SA}

This work is licensed under Creative Commons Attribution-NonCommercial-ShareAlike 4.0 International License. 